Resenhas 



\section{Letras e imagens: \\ representações da modernidade na América Latina}

Helton Rubiano de Macedo*

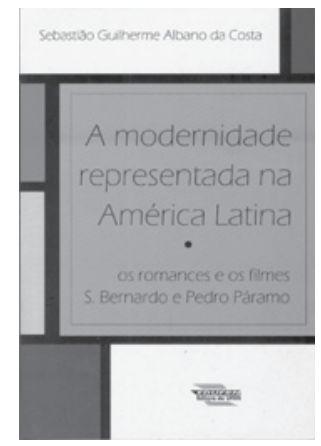

COSTA, Sebastião Guilherme Albano da.

A modernidade representada na América Latina: os romances e os filmes S. Bernardo e Pedro Páramo. Natal: EDUFRN, 2010. $304 p$.

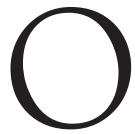

debate comunicacional inscrito no âmbito regional da América Latina dispõe agora de mais uma referência. Em A modernidade representada na América Latina, Sebastião Albano da Costa trata da análise dos romances S. Bernardo (1934), de Graciliano Ramos, e Pedro Páramo (1955), de Juan Rulfo, bem como de suas adaptações homônimas para o cinema, realizadas por Leon Hirszman (1971) e Carlos Velo (1966), respectivamente. Desse recorte, surgem as interpretações para compor um quadro do período moderno no continente latino-americano.

$\mathrm{O}$ autor parte de temas relativos à produção cultural institucionalizada na América Latina, estabelecendo relações com os processos de formação da imaginação regional na qual se coadunam as obras de cunho artístico e as conjunturas sociopolíticas e econômicas sob as quais se inserem. Objetiva, desse modo, descrever as estruturas de significação das referidas produções. A partir disso, procura delinear os traços do período moderno em representações conformadas, especialmente na América Latina, foco da pesquisa, em fatores idiossincráticos, que, por sua vez, interferiam, especialmente nos casos do Brasil e do México, na criação dos consensos que davam forma ao sistema da modernidade.

\footnotetext{
* Mestrando do Programa de Pós-Graduação em Estudos da Mídia - PPGEM - da Universidade Federal do Rio Grande do Norte. Natal-RN, Brasil.
} 
O autor apresenta, considerando as premissas da história cultural da América Latina, o cenário sustentado para que os romances e os filmes S. Bernardo e Pedro Páramo se configurassem como marcos no quadro de representação regional. Um método que, segundo o próprio autor, combina a observação de sua composição retórica e poética com indagações sobre os modos pelos quais sua estrutura é impregnada pela perspectiva histórica e estética, como também pelas circunstâncias peculiares das sociedades nas quais as representações foram configuradas. Essa observação findou apresentando um processo subjacente, no qual estão implicadas premissas do pensamento comunicacional, as quais contribuem sobremaneira na formação do imaginário nacional dos países latino-americanos.

As raízes da investigação se sustentam nos estudos culturais, na teoria narrativa e na teoria da recepção. A partir delas, ramificamse outras disciplinas também implicadas, como a história, a sociologia, a teoria literária e a do pensamento comunicacional, a qual, segundo o autor, de certa maneira, compreende todas as demais.

O estudo justifica-se na intenção de delinear o perfil sintomático das referidas obras sob as circunstâncias sociais de produção, distribuição e recepção de bens culturais no continente latinoamericano. $\mathrm{O}$ autor ainda propõe atribuir à chamada produção simbólica uma estrutura a partir da qual se articulam valores originados da realidade textual e extratextual e geradores, mediados por outros agentes, de determinadas modalidades de compreensão.

A investigação defende que as configurações das representações artísticas resultaram em um sensorium da América Latina, transparecendo estruturas sociopolíticas e econômicas características do período no qual as obras foram concebidas. Para tanto, é traçada uma genealogia do campo cultural latino-americano, destacando suas particularidades. Trata-se de um quadro denso, fundamental para apoiar as descrições e interpretações que irão se seguir.

A partir do segundo capítulo, o autor discorre sobre o instituto dos significados, as políticas culturais e os movimentos artísticos no Brasil e no México, no período de 1920 a 1975; expõe também os hábitos da tradição regionalista no Brasil, da novela de la Revolución no México e seus correlatos no cinema; por fim, inves- 
tiga o ensaísmo na América Latina e a história como índice em S. Bernardo e Pedro Páramo, incluindo as obras em seus formatos literário e cinematográfico. Nesse item, é exposta a tentativa de articular políticas culturais no Brasil e no México no século 20, destacando períodos marcantes para a cultura desses países, como os mandatos de Getúlio Vargas e a ditadura militar no Brasil, e os governos pós-revolucionários no México. A partir desse cenário, objetiva expor as implicações dessas configurações no tocante aos significados das produções culturais institucionalizadas. Além disso, articula os resultados dessas descrições com os movimentos artísticos desenvolvidos nos dois países.

No capítulo 3, é realizada uma descrição das obras em estudo de modo operacional, afinada com uma prática de leitura especializada, e sustentada na teoria da narrativa. $O$ autor esclarece, desde o início, que essa descrição pode ser mediadora de significados e não tradutora deles próprios, pois não possui as maneiras de construí-los. Assim, destaca que a referida descrição relaciona e orienta os significados das obras em estudo a partir de uma estrutura que codifica ou que se refere a outros códigos, arraigados por outras marcas. Desse modo, fica claro que não se pretende firmar o significado das obras em análise, mas sim propor um conjunto de alternativas.

No capítulo 4, é explorado o fenômeno da adaptação, nesse caso, focada nas duas obras em análise - ambas expressões literárias transpostas ao cinema. $\mathrm{O}$ autor investe em analisar a tradição representativa em que os romances e os filmes estão circunscritos com o intuito de desnudar os consensos simbólicos pelos quais as obras são permeadas. Consensos que, de alguma forma, estão presentes tanto nos romances quanto nos filmes, mas que podem, a partir de novas conjunturas, alterar-se no intervalo da publicação do impresso e da sua produção audiovisual.

Em suas considerações finais, o autor ressalta que o interesse da sua investigação reside em explorar como a imaginação consensual foi legitimada pelos discursos simbólicos institucionalizados. Sobre isso, reafirma que as expressões da cultura institucionalizada exprimiam não apenas a estética moderna, mas também o cenário no qual os projetos da modernidade 
epistemológica e da modernização política e social se emergiam e eram levados a cabo.

Vale ressaltar que a investigação apresentada é mais do que uma exposição das representações culturais dos países em destaque, Brasil e México. Trata-se de recortes expoentes de uma cultura latino-americana que, apesar de severas divergências entre seus países membros, possui traços singulares que a torna particularmente complexa e instigante. A modernidade representada na América Latina é também um esforço inspirador para outros estudos da representação, que também podem incluir novos olhares sobre novos campos ou fenômenos, cujas imagens podem ser levadas não apenas à literatura ou ao cinema, mas a qualquer outra forma de construir, midiaticamente, considerando a influência de uma gama de fatores, a realidade da qual somos parte. 